\title{
Behavior of a Virulent Strain Derived from Agrobacterium radiobacter Strain K84 After Spontaneous Ti Plasmid Acquisition
}

\author{
María José López-López, Begonya Vicedo, Natividad Orellana, Jaime Piquer, and María M. López
}

Instituto Valenciano de Investigaciones Agrarias, Apartado Oficial, Moncada, 46113 Valencia, Spain.

Accepted for publication 30 December 1998.

\begin{abstract}
López-López, M. J., Vicedo, B., Orellana, N., Piquer, J., and López, M. M. 1999. Behavior of a virulent strain derived from Agrobacterium radiobacter strain K84 after spontaneous Ti plasmid acquisition. Phytopathology 89:286-292.

The behavior of the virulent transconjugant K84N6 derived from Agrobacterium radiobacter strain $\mathrm{K} 84$ after spontaneous Ti plasmid transfer in crown gall tissue in a biocontrol experiment was studied and compared with the behavior of the wild-type A. tumefaciens donor of the Ti plasmid.

the transconjugant to catabolize nopaline. Host range, ability to induce tumors in several fruit trees, and stability of the pathogenic determinants in isolates from tumors did not differ between the strains. Nevertheless, in a biocontrol experiment, the transconjugant was not controlled by strain K84 or K1026 in peach $\times$ almond hybrids and survived in the plant rhizosphere for 9 months with larger population densities than the wild strain. The appearance and persistence in soil of strains harboring a $\mathrm{Ti}$ plasmid in the K84 chromosomal background could represent a risk in the medium term, if they show good competitive ability.
\end{abstract} The main difference between the strains was a greatly reduced ability of
Agrobacterium tumefaciens is the causal agent of crown gall, a neoplastic disease of plants. Virulent bacteria contain a tumor-inducing Ti plasmid that is responsible for plant cell transformation via the introduction of T-DNA into the plant chromosome. Many functions involved in pathogenicity are encoded on the Ti plasmid including the synthesis of auxins and cytokinins, opine production, and opine utilization $(12,29)$. Several authors demonstrated that host-range specificity can be determined by genes located in the T-DNA region and in the vir region of the Ti plasmid $(2,39)$.

The Ti plasmid is a conjugative plasmid whose transfer to other bacterial recipients is induced by several opines (30). Transfer of the Ti plasmid to avirulent strains of Agrobacterium was reported in several in vitro experiments using the promiscuous plasmid RP4 (3) or conjugal opines as transfer inducers $(7,30)$ and also was detected in planta (13).

A. radiobacter strain $\mathrm{K} 84$ is a very efficient biocontrol agent of crown gall (21). Strain K84 harbors three plasmids: pAgK434, pNoc, and pAgK84. Plasmid pAgK84 encodes the production of agrocin 84 , an antibiotic involved in the biocontrol of crown gall (14). Transfer of pAgK84 from K84 to strains of A. tumefaciens has been reported $(26,37,42,43)$. Strain K1026, a $\mathrm{Tra}^{-}$deletion mutant, was constructed to eliminate the possibility of this transfer (11) and was proposed as a safe substitute for K84 $(10,41,43)$.

Several authors previously suggested the possibility that strain K84 could acquire the Ti plasmid by conjugal transfer (21). However, it was assumed that strain K84 was protected against Ti-plasmid acquisition because of the presence of pNoc, a conjugative nononcogenic plasmid-encoding nopaline catabolism that belongs to the same incompatibility group as the Ti plasmid (8). Therefore, both plasmids are unable to replicate in the same cell. Nevertheless, it was demonstrated in our laboratory that Ti-plasmid transfer

Corresponding author: M. M. López; E-mail address: mlopez@master.ivia.es

Publication no. P-1999-0210-01R

(C) 1999 The American Phytopathological Society from A. tumefaciens to strain K84 can spontaneously occur in planta under semi-natural conditions (42). This transfer event was detected only in one tumor in a biocontrol experiment using strain K84 against a strain of $A$. tumefaciens biovar 1 , which utilized nopaline and was sensitive to agrocin 84 . The transconjugants induced tumors, produced agrocin 84 , and contained a Ti plasmid with the same size as that of the donor strain. Further analysis demonstrated that the transconjugant strain K84N6 harbored a functional $\mathrm{Ti}$ plasmid that differed from that of the donor strain 325-4 (42), suggesting a recombination event between the incompatible plasmids pNoc and pTi.

The frequency at which the Ti plasmid can be transferred from pathogenic strains to strain K84 in the field is not yet known, as well as the repercussion on biocontrol effectiveness. Nevertheless, such pTi transfer could be a potential threat to the use of biocontrol strains K84 and K1026, because the transconjugant K84N6 causes crown gall, produces agrocin 84 , and is immune to the antibiotic. For this reason, in this study, we evaluated the behavior of this transconjugant strain, comparing it with that of the virulent Ti-plasmid donor. The ability of K84N6 to induce tumors, survive in the rhizosphere, and retain virulence in the soil and in the tumor environment were studied. The efficacy of biocontrol strains K84 and K1026 against this new strain also was analyzed in order to evaluate the potential threat of this transconjugant to the commercial use of these biocontrol strains.

\section{MATERIALS AND METHODS}

Bacterial strains. The characteristics of the strains used are summarized in Table 1. A. tumefaciens K84N6 was obtained after spontaneous Ti-plasmid transfer from the wild strain 325-4 (donor) to strain K84 (recipient). It was isolated from a tumor of a peach $\times$ almond GF677 hybrid (Persica vulgaris Mill. $\times$ Prunus dulcis Weeb) in a biological control experiment conducted under greenhouse conditions in pots with a substrate inoculated with strain 325-4 (42). Strains K84 and K1026 of A. radiobacter were used in the biological control experiments. A. radiobacter strain K1026 was 
supplied by G. C. Bullard (Bio-care Technology, Woy-Woy, Australia). A. tumefaciens strain C58 was used as the indicator strain in assays of agrocin 84 production. Bacteria were grown in nonselective peptone yeast glycerol agar (PYGA) medium (5 $\mathrm{g}$ of bactopeptone per liter [Oxoid Ltd., Basingstoke, England], $3 \mathrm{~g}$ of yeast extract per liter [Oxoid Ltd.], $10 \mathrm{ml}$ of glycerol per liter, and $20 \mathrm{~g}$ of agar per liter) for all the experiments (19).

Opine utilization. Nopaline and octopine utilization was measured after growing strains 325-4, K84N6, and K84 individually for $72 \mathrm{~h}$ at $26^{\circ} \mathrm{C}$ in minimal medium $\mathrm{S}$ (17) containing either nopaline or octopine as the sole carbon and nitrogen source at a final concentration of $100 \mu \mathrm{g} / \mathrm{ml}$. Utilization of nopaline and octopine was studied by determining the amount of the substrates at 24, 48, and $72 \mathrm{~h}$ after incubation. This experiment was conducted twice. Presence of the two opines was measured according to the method of Lippincott et al. (16), with some modifications (17), as follows: $1 \mathrm{ml}$ of the culture supernatant was supplemented with $1 \mathrm{ml}$ of $0.9 \mathrm{M}$ $\mathrm{NaOH}$ and $1 \mathrm{ml}$ of $\alpha$-naphthol-diacetyl (17). After shaking, samples were allowed to settle for $30 \mathrm{~min}$ at room temperature and their optical density was measured in a Titertek Multiskan (Flow Laboratories, Irvine, Scotland) at $450 \mathrm{~nm}$. At least four replicates were used for each strain and opine, and each replicate consisted of four wells. Standard curves for octopine and nopaline were constructed.

Host range. Host-range assays were performed on greenhousegrown plants by inoculation with $A$. tumefaciens strain 325-4 or the transconjugant strain K84N6. Bacterial suspensions prepared with 48-h cultures were used to inoculate the stems of the plants after they were wounded with a scalpel. Eight herbaceous species and two woody species were used as host plants. The inoculated hosts were tomato (Lycopersicon esculentum Mill.), tobacco (Nicotiana tabacum L.), sunflower (Helianthus annuus L.), datura (Datura stramonium L.), bean (Phaseolus vulgaris L.), eggplant (Solanum melongena L.), watermelon (Citrullus lanatus (Thub.) Mansfed), vinca (Vinca rosea L.), rose (Rosa subsp. L. Hort indica), and grapevine (Vitis vinifera L.). Every plant was inoculated at two or three different points with a dose of $2 \times 10^{7} \mathrm{CFU}$ per wound. The experiment was performed twice. The number of inoculated plants of every host is indicated in Table 2. Plants inoculated with every strain were randomly assigned, and tumor formation was recorded 2 months later.

Virulence assays. Virulence assays were performed on 1-yearold seedlings of cherry (Prunus avium L.) cv. Santa Lucía, apple (Malus domestica Borkh.) cv. Pajam 1, pear (Pyrus communis L.) cv. Kirchensaller, and peach $\times$ almond hybrids (Persica vulgaris Mill. $\times$ Prunus dulcis Weeb) GF677 and Adafuel. Before planting, strain $325-4$ or K84N6 was introduced individually into a sterile potting mix containing $50 \%$ peat and $50 \%$ sand, according to the methods described by Vicedo et al. (43), to give a final concentration of $10^{7} \mathrm{CFU} / \mathrm{g}$ of substrate. Prior to planting, the roots were pruned and the crowns were superficially wounded with a sterile scalpel. A total of 10 to 25 plants of every species was inoculated with each strain. The plants were arranged in a completely randomized design in order to minimize the environmental effects in the greenhouse. After 9 months, plants were dug up and evaluated for crown gall on the basis of the number of diseased plants and number and size of tumors per infected plant. A similar experiment was performed twice using 3-week-old tomato plants. In all, 60 tomato plants were inoculated with every strain. Tumor formation on roots was observed and analyzed after 4 months.

Pathogenicity stability. Stability of genes encoding pathogenicity was studied in two experiments in agrobacteria isolated from tumors obtained 40 days after inoculation of tomato stems with strain $325-4$ or K84N6 $\left(4 \times 10^{6} \mathrm{CFU}\right.$ per wound). Ten tumors obtained with every strain were selected to analyze the Agrobacterium isolates. Each tumor was comminuted in sterile water and appropriate dilutions were plated on semiselective media of biovar 1, described by Schroth et al. (36), or biovar 2, described by New and Kerr (23), to select strains 325-4 and K84N6, respectively. The Agrobacterium spp.-like colonies were counted, and 30 colonies per tumor were purified, assessed for Agrobacterium spp. characteristics, and tested for pathogenicity on tomato plants.

Biological control of crown gall. One-year-old plants of the GF677 hybrid were used for biocontrol assays performed under controlled conditions in the greenhouse with 60 to $90 \%$ relative humidity and temperatures between 20 and $26^{\circ} \mathrm{C}$. Just before planting, plants were superficially wounded in the crown with a sterile scalpel and dipped into suspensions of peat preparations of $\mathrm{K} 84$ or the genetically modified strain K1026 (peat/water, 1:1, wt/vol; $10^{9} \mathrm{CFU} / \mathrm{ml}$ ), prepared

TABLE 2. Host range of Agrobacterium tumefaciens strains 325-4 and K84N6 ${ }^{\mathrm{u}}$

\begin{tabular}{|c|c|c|c|c|c|c|}
\hline \multirow[b]{2}{*}{ Plant } & \multicolumn{2}{|c|}{ Tumor induced $^{\mathrm{v}}$} & \multicolumn{2}{|c|}{ Experiment $1^{\mathrm{w}}$} & \multicolumn{2}{|c|}{ Experiment 2} \\
\hline & $325-4$ & K84N6 & $325-4$ & K84N6 & $325-4$ & K84N6 \\
\hline Tomato & + & + & $30 / 30$ & $29 / 29$ & $25 / 25$ & $23 / 25$ \\
\hline Tobacco & + & + & $10 / 10$ & $10 / 10$ & $24 / 24$ & $22 / 24$ \\
\hline Sunflower & + & + & $9 / 9$ & $8 / 8$ & $25 / 27$ & $24 / 25$ \\
\hline Datura & + & + & $9 / 10$ & $10 / 10$ & $19 / 29$ & $20 / 29$ \\
\hline Bean & + & + & $8 / 9$ & $9 / 10$ & $\mathrm{ND}^{\mathrm{x}}$ & ND \\
\hline Eggplant & $d++^{y}$ & $d+$ & $10 / 10$ & $9 / 9$ & ND & ND \\
\hline Watermelon & + & + & $7 / 10$ & $9 / 10$ & $19 / 30$ & $20 / 29$ \\
\hline Vinca & + & + & $8 / 8$ & $6 / 9^{z}$ & $26 / 26$ & $24 / 28^{z}$ \\
\hline Rose & + & + & $1 / 5$ & $1 / 5$ & ND & ND \\
\hline Grapevine & + & + & $5 / 5$ & $5 / 6$ & ND & ND \\
\hline
\end{tabular}

u Results of two different experiments are shown.

v Plants were inoculated at the stem with A. tumefaciens strains 325-4 or K84N6 with a dose of $2 \times 10^{7} \mathrm{CFU}$ per wound. Each plant was inoculated at two or three different points on the stem. Tumor formation was recorded 2 months later.

${ }^{\mathrm{w}}$ Number of galled plants per inoculated plant. Number of galled plants produced by strains 325-4 and K84N6 were compared within each host by comparison of proportions using the approximate $Z$ test.

$x \mathrm{ND}=$ not determined .

${ }^{\mathrm{y}} \mathrm{d}+$ indicates small proliferations at the inoculation site.

${ }^{\mathrm{z}}$ Indicates a significant difference $(P<0.05)$ between strains $325-4$ and K84N6.

TABLE 1. Bacterial strains, characteristics, and plasmids of Agrobacterium spp.

\begin{tabular}{|c|c|c|c|c|c|}
\hline Strain & Biovar & $\begin{array}{l}\text { Sensitivity to } \\
\text { agrocin } 84^{\mathrm{w}}\end{array}$ & $\begin{array}{l}\text { Opine } \\
\text { utilization }^{\mathrm{x}}\end{array}$ & Plasmid size $(\mathrm{kb})^{\mathrm{y}}$ & Description \\
\hline \multicolumn{6}{|c|}{ A. tumefaciens } \\
\hline $325-4$ & 1 & $\mathrm{~S}$ & Nop, Oct ${ }^{\mathrm{z}}$ & pTi 325-4 (196), pAt 325-4 (151) & From a peach tumor in Spain, donor of Ti plasmid \\
\hline K84N6 & 2 & $\mathrm{R}$ & $\begin{array}{l}\text { Analyzed in } \\
\text { this study }\end{array}$ & pAgK434 (>300), pTi K84N6 (190), pAgK84 (47.7) & $\begin{array}{l}\text { Transconjugant obtained after Ti-plasmid transfer } \\
\text { from strain } 325-4 \text { to } A \text {. radiobacter strain K84 }\end{array}$ \\
\hline C58 & 1 & $\mathrm{~S}$ & Nop & pAtC58 (410), pTiC58 (195) & Indicator of agrocin 84 sensitivity \\
\hline \multicolumn{6}{|c|}{ A. radiobacter } \\
\hline K84 & 2 & $\mathrm{R}$ & Nop, Oct $^{z}$ & pAgK434 (>300), pNoc (173), pAgK84 (47.7) & Biocontrol agent of crown gall \\
\hline K1026 & 2 & $\mathrm{R}$ & Nop, Oct ${ }^{\mathrm{z}}$ & pAgK434 (>300), pNoc (173), pAgK1026 (41.8) & $\begin{array}{l}\text { Strain K84 with } \mathrm{Tra}^{-} \text {agrocin } 84 \text { plasmid (11), } \\
\text { biocontrol agent of crown gall }\end{array}$ \\
\hline
\end{tabular}

${ }^{\mathrm{w}} \mathrm{R}=$ resistant and $\mathrm{S}=$ sensitive. Sensitivity to agrocin 84 was determined by method of Stonier (38).

${ }^{x}$ Nop $=$ nopaline and Oct $=$ octopine. Opine utilization was determined by method of López et al. (17).

y Characteristics of plasmids were described by Vicedo et al. (42).

${ }^{\mathrm{z}}$ Octopine is slowly degraded by these strains. 
as previously described (19). One hundred plants were used per treatment in individual pots and were arranged in a completely randomized design. Before planting in pots, the sterile substrate (50\% peat, $50 \%$ sand) was inoculated with strain $325-4$ or strain K84N6 of A. tumefaciens as described above, to a final concentration of $10^{7} \mathrm{CFU} / \mathrm{g}$ of substrate. Plants were grown for 9 months in a contained greenhouse and, after harvest, evaluated for the number of diseased plants and number and weight of tumors per plant.

Root colonization by Agrobacterium. Population sizes of $A$. tumefaciens and $A$. radiobacter in the rhizosphere of plants from the biocontrol experiment described above were determined 9 months after inoculations. For each strain and treatment, six plants were randomly selected after harvest. Roots ( $10 \mathrm{~g}$ per plant) were soaked in $0.25 \times$ Ringer solution (35) with $0.05 \%$ Tween 20 and shaken for $45 \mathrm{~min}$ at $200 \mathrm{rpm}$ on an Orbit Environ Shaker (Lab-Line Instruments, Inc., Melrose Park, IL). The number of bacteria from the roots was counted after plating dilutions of washings on semiselective media. Strain 325-4 was isolated on a medium described by Schroth et al. (36) for biovar 1 strains. Strains K84N6, K84, and K1026 were isolated on a semiselective medium for biovar 2 (23). A total of 20 to 30 Agrobacterium spp.-like colonies per plate were purified and analyzed. Several tests were used to distinguish among the different strains (Table 1). Specific biovar tests were conducted according to Moore et al. (20) to distinguish and confirm biovar 1 (strain 325-4) or 2 (strains K84 and K84N6). Agrocin 84 production by strains $\mathrm{K} 84$ and K84N6 was assayed according to

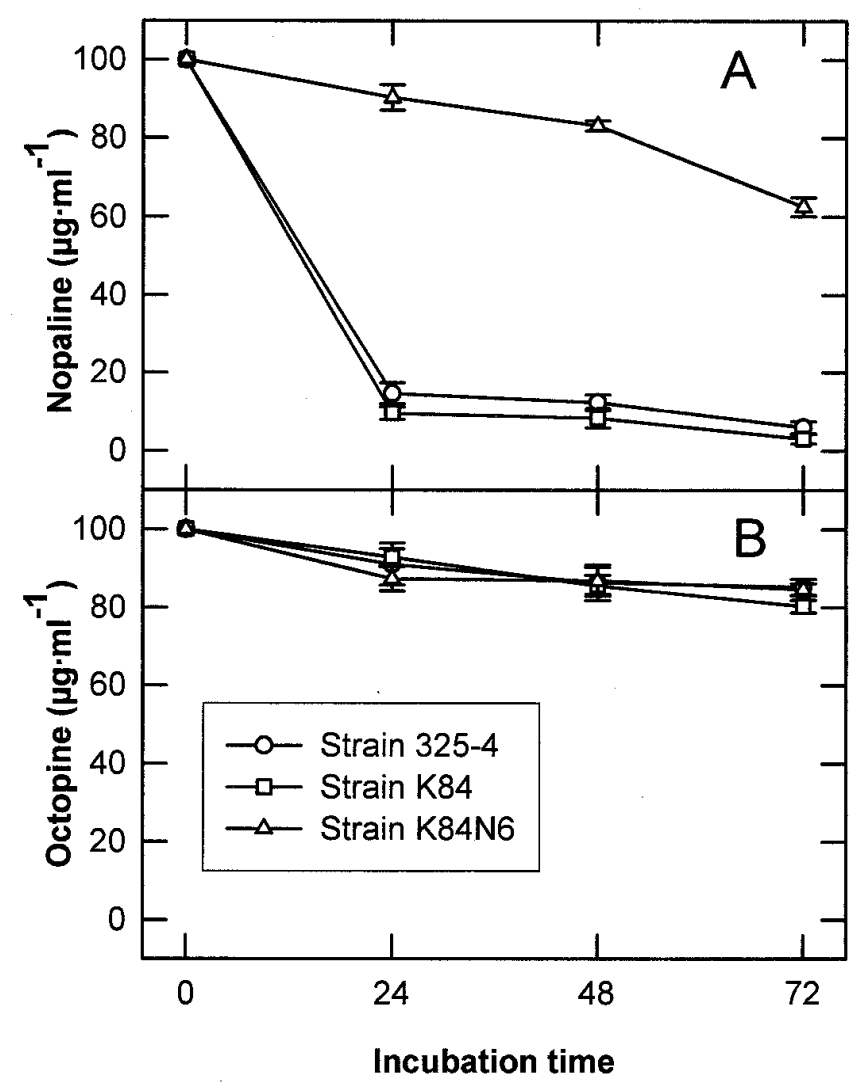

Fig. 1. Utilization of nopaline and octopine by Agrobacterium radiobacter strains 325-4 and K84 and the transconjugant strain K84N6 after growing for $72 \mathrm{~h}$ in a minimal medium supplemented with nopaline and octopine as a sole carbon and nitrogen source. Opine concentration was measured in the bacterial supernatant after 24,48 , and $72 \mathrm{~h}$ of incubation, according to López et al. (17) in two experiments. Data are mean of four replicates consisting in four wells each. Error bars represent the standard error of the mean. At 24, 48, and $72 \mathrm{~h}$, nopaline levels were reduced significantly less $(P<0.05)$ by strain K84N6 than by strains 325-4 and K84; strains 325-4 and K84 did not differ significantly. There were no differences among strains in octopine utilization. the Stonier procedure (38). Pathogenicity on tomato plants was used to distinguish between pathogenic (325-4 and K84N6) and nonpathogenic (K84 and K1026) strains. Plasmids profiles of selected colonies were analyzed as described by Vicedo et al. (43).

Statistical analysis. Statistical analysis of data was performed using the statistical analysis package SPSS 6.0 for Windows (SPSS Inc., Chicago). Opine utilization was compared among strains by analysis of variance (ANOVA), and means were separated by the least significant difference (LSD) test. To compare host range and virulence of strains K84N6 and 325-4, data of number of infected plants were analyzed by comparison of proportions using the approximate $Z$ test (44). Quantitative data (number and size of tumors) were analyzed using Student's $t$ test. In biocontrol and root colonization assays, a two-way ANOVA (two factors: strain and treatment) was used to analyze data of number of infected plants, number and weight of tumors per plant, and population sizes. When significant interactions were found, the LSD procedure was used to compare means.

\section{RESULTS}

Octopine and nopaline utilization. After incubation for $24 \mathrm{~h}$, strain 325-4 reduced the nopaline level from 100 to $14.6 \mu \mathrm{g} / \mathrm{ml}$, and strain K84 reduced the nopaline level to $8.4 \mu \mathrm{g} / \mathrm{ml}$. No significant differences $(P>0.05)$ were observed between these two strains. Strain K84N6 decreased nopaline levels very slightly (91.6, 83.2 , and $62.6 \mu \mathrm{g} / \mathrm{ml}$ after incubation for 24,48 , and $72 \mathrm{~h}$, respectively), and the population size of this strain did not increase during the assay (data not shown). At 24, 48, and $72 \mathrm{~h}$, nopaline levels were reduced significantly less $(P<0.05)$ by K84N6 than by strains $325-4$ and K84. There were no significant differences among strains K84N6, 325-4, and K84 in octopine utilization, and octopine levels decreased slightly during the incubation (Fig. 1).

Host range. Strains 325-4 and K84N6 were able to induce tumors in tomato, tobacco, sunflower, grapevine, datura, bean, watermelon, and vinca, but only small excrescences were observed in eggplants. Except on vinca, strains 325-4 and K84N6 did not differ significantly in virulence as measured by the number of diseased plants (Table 2).

Virulence assays. The virulence of strains 325-4 and K84N6 was tested on several fruit trees considered typical host plants for A. tumefaciens. The incidence of crown gall was high (80 to $100 \%$ galled plants) when the most susceptible hosts, peach $\times$ almond hybrids Adafuel and GF677, were grown in potting mix amended with strain 325-4. Less susceptible hosts (pear and apple) showed much lower disease incidence (4 to $8 \%$ galled plants). Similar results were obtained when the transconjugant strain K84N6 was used. No statistically significant differences $(P>0.05)$ in the number of infected plants nor in the number and size of tumors per infected plant were observed when using strains 325-4 and K84N6 (Table 3). In the experiments with tomato plants, the transconjugant strain K84N6 resulted in significantly fewer galled plants than strain 325-4 (Table 3).

Pathogenicity stability. The transconjugant strain was detected in tumors in significantly $(P<0.05)$ higher populations $\left(1.1 \times 10^{7}\right.$ CFU per tumor) than the wild type $\left(2.1 \times 10^{6} \mathrm{CFU}\right.$ per tumor $)$ after 40 days. However, when the pathogenicity of the recovered isolates was tested, there were no significant differences in the percentage of pathogenic colonies (96.8 and $97.8 \%$ from strains 325-4 and K84N6, respectively). These results demonstrated that the pathogenic determinants of strain K84N6 remained stable in tomato tumors at least to the same extent as the wild-type strain 325-4.

Biological control. A. tumefaciens strains $325-4$ and K84N6 did not differ practically in ability to cause crown gall. The factorial ANOVA analysis revealed significant $A$. tumefaciens strain $\times$ treatment interactions in the number of infected plants and the number of tumors. The LSD test revealed that strains K84 and K1026 were very efficient in controlling galls induced by strain 
$325-4$, because they significantly $(P<0.05)$ reduced the percentage of infected plants (4.0 and 7.0\%, respectively) as compared with the nontreated control $(91.0 \%)$ (Table 4). There was no difference between crown gall suppression by K84 and K1026. In contrast, in potting mix with the transconjugant strain K84N6, a statistically significant but biologically ineffective reduction on crown gall incidence occurred in K84- or K1026-treated plants (84.3 and $81.7 \%$ of infected plants, respectively) as compared with the nontreated plants $(97.5 \%)$. No significant differences were observed between treatments with K84 or K1026 against K84N6 (Table 4).

The weight of the tumors caused by strains $325-4$ and K84N6 on K84- or K1026-treated plants was significantly less than that on nontreated controls $(P<0.05)$. The transconjugant strain induced more galls per plant than strain 325-4 $(P<0.05)$ in nontreated and in K84- or K1026-treated plants. The number of tumors per plant differed significantly between nontreated and treated plants growing in soil inoculated with strain K84N6 (Table 4).

Root colonization by Agrobacterium strains. At 9 months after soil inoculation, populations of the Agrobacterium strains in the rhizosphere were measured in the biocontrol experiment described above (Fig. 2). A factorial ANOVA test was used to analyze in two separate analyses the population sizes of A. tumefaciens (strains 325-4 and K84N6) and A. radiobacter (strains K84 and K1026). In both cases, the analysis revealed significant $A$. tumefaciens strain $\times$ treatment interactions. For $A$. tumefaciens populations, the LSD analysis showed that the population size of strain 325-4 was significantly greater $(P<0.05)$ in the rhizosphere of nontreated plants $\left(2 \times 10^{5} \mathrm{CFU} / \mathrm{g}\right.$ of root $)$ than in the rhizosphere of K84- or K1026-treated plants $\left(8.6 \times 10^{3}\right.$ and $1.3 \times 10^{4} \mathrm{CFU} / \mathrm{g}$ of root, respectively) (Fig. 2A). After 9 months of incubation, the population size of strain K84N6 on nontreated plants was $3.6 \times 10^{6}$ $\mathrm{CFU} / \mathrm{g}$ of root and was 3.2 and $2.1 \times 10^{6} \mathrm{CFU} / \mathrm{g}$ of root on plants treated with strains K84 and K1026, respectively. The population size of strain K84N6 did not differ significantly between nontreated plants and plants treated with strains K84 or K1026 (Fig. 2B). In

TABLE 3. Incidence and severity of grown gall on hosts grown in potting mix amended with Agrobacterium tumefaciens strains 325-4 or K84N6

\begin{tabular}{|c|c|c|c|c|c|}
\hline Host & Strain $^{t}$ & $\begin{array}{l}\text { No. of } \\
\text { plants } \\
\text { analyzed }\end{array}$ & $\begin{array}{l}\text { Infected } \\
\text { plants } \\
(\%)^{\mathrm{u}}\end{array}$ & $\begin{array}{l}\text { No. of tumors/ } \\
\text { infected plant }^{\mathrm{V}}\end{array}$ & $\begin{array}{c}\text { Size of } \\
\text { tumors }(\mathrm{cm}) / \\
\text { infected plant }\end{array}$ \\
\hline \multirow[t]{2}{*}{ Cherry } & $325-4$ & 10 & 50.00 & $1.00 \pm 0.0$ & $4.20 \pm 0.6$ \\
\hline & K84N6 & 10 & 80.00 & $1.62 \pm 0.4$ & $3.02 \pm 0.6$ \\
\hline \multirow[t]{2}{*}{ Pear } & $325-4$ & 25 & 4.00 & $1.00^{\mathrm{w}}$ & $4.00^{w}$ \\
\hline & K84N6 & 24 & 4.15 & $1.00^{\mathrm{w}}$ & $4.00^{w}$ \\
\hline \multirow[t]{2}{*}{ Apple } & $325-4$ & 23 & 8.69 & $1.50 \pm 0.5$ & $1.96 \pm 0.5$ \\
\hline & K84N6 & 26 & 3.84 & $1.00^{\mathrm{w}}$ & $1.50^{\mathrm{w}}$ \\
\hline \multirow[t]{2}{*}{ Adafuel $^{\mathrm{x}}$} & $325-4$ & 6 & 100.00 & $1.33 \pm 0.2$ & $2.65 \pm 0.4$ \\
\hline & K84N6 & 5 & 80.00 & $2.25 \pm 0.9$ & $3.55 \pm 0.3$ \\
\hline \multirow[t]{2}{*}{ GF677x } & $325-4$ & 21 & 95.23 & $3.35 \pm 0,5$ & $1.88 \pm 0.1$ \\
\hline & K84N6 & 22 & 100.00 & $3.59 \pm 0,4$ & $1.46 \pm 0.1$ \\
\hline \multirow[t]{4}{*}{ Tomato } & $325-4$ & 59 & 86.44 & $4.90 \pm 0.5$ & $0.04 \pm 0.0$ \\
\hline & K84N6 & 63 & $44.44^{y}$ & $2.03 \pm 0.3^{y}$ & $0.71 \pm 0.01^{\mathrm{y}}$ \\
\hline & $325-4$ & 34 & 97.06 & $3.84 \pm 0.4$ & $\mathrm{ND}^{\mathrm{z}}$ \\
\hline & K84N6 & 32 & $87.50^{y}$ & $2.68 \pm 0.2^{y}$ & ND \\
\hline
\end{tabular}

t One-year-old seedlings of different fruit trees and 3-week-old tomato plants were planted in sterile soil amended with A. tumefaciens (325-4 or K84N6 to a final concentration of $10^{7} \mathrm{CFU} / \mathrm{g}$ of substrate. Tumor formation in the roots and crown was recorded 9 months later for fruit trees and 4 months later for tomato plants.

u Number of infected plants produced by strains 325-4 and K84N6 were compared within each host by comparison of proportions using the approximate $Z$ test. No comparison was made between different hosts.

${ }^{v}$ Number and size of tumors (mean \pm standard error) produced by strains 325-4 and K84N6 were compared using Student's $t$ test. No comparison was made between different hosts.

w Only one tumor was obtained.

${ }^{x}$ Peach $\times$ almond hybrid.

y Indicates a significant difference $(P<0.05)$ between strains $325-4$ and K84N6.

${ }^{\mathrm{z}} \mathrm{ND}=$ not determined. every case, the population size of transconjugant strain K84N6 was significantly greater $(P<0.05)$ than that of donor strain 325-4.

After 9 months in a substrate inoculated with strain 325-4, strains K84 and K1026 maintained very high population sizes. Population sizes of strains K84 and K1026 were $3.5 \times 10^{6}$ and $9.0 \times 10^{5}$ $\mathrm{CFU} / \mathrm{g}$ of root, respectively (Fig. 2A). In contrast, when the soil was amended with strain K84N6, the population sizes of strains K84 and K1026 were 1.8 and $1.7 \times 10^{2} \mathrm{CFU} / \mathrm{g}$ of root, respectively (Fig. 2B). No significant differences were observed between population sizes of strains K84 and K1026 (Fig. 2B). Population sizes of strains $\mathrm{K} 84$ and $\mathrm{K} 1026$ were significantly lower $(P<0.05)$ in the substrate inoculated with strain K84N6 than in the substrate inoculated with strain 325-4 (Fig. 2A and B).

\section{DISCUSSION}

Plasmid transfer between different Agrobacterium strains or related species can result in transconjugants with characteristics and behaviors different from those of the donor and the recipient strains $(15,24,32)$ or in transconjugants with characteristics similar to their parental strains (37). In this paper, the behavior of the pathogenic transconjugant strain K84N6, derived from strain K84 of A. radiobacter after spontaneous Ti-plasmid acquisition from strain 325-4 of A. tumefaciens (42), is described.

The opine-utilization assays demonstrated that transconjugant strain K84N6 metabolized nopaline slightly, whereas its parental strains, 325-4 and K84, utilized this opine very efficiently. As we previously described (42), the Ti plasmid of the transconjugant was modified as a consequence of the plasmid transfer event, possibly due to a recombination with the resident pNoc plasmid of strain K84. The new Ti plasmid of K84N6 appeared to have a deletion in the left part of the nopaline catabolic region (42), which contains the ocd, arc, and nox $A$ genes implicated in nopaline degradation $(34,46)$. This fact could explain the result that the new strain was greatly reduced in its ability to utilize nopaline. According to the opine concept (29), strains having the ability to catabolize an opine should be more competitive in the tumor environment than those lacking this trait. Thus, this could imply a disadvantage for

TABLE 4. Effects of treatments with the strains K84 and K1026 on the infection caused by Agrobacterium tumefaciens strain 325-4 and the transconjugant strain K84N6

\begin{tabular}{|c|c|c|c|c|c|}
\hline Strain $^{\mathrm{x}}$ & Treatment $^{\mathrm{y}}$ & $\begin{array}{c}\text { No. of } \\
\text { plants } \\
\text { analyzed }^{\mathrm{z}}\end{array}$ & $\begin{array}{c}\text { Infected } \\
\text { plants } \\
(\%)\end{array}$ & $\begin{array}{c}\text { Weight of } \\
\text { tumors/ } \\
\text { infected plant }\end{array}$ & $\begin{array}{l}\text { No. of tumors/ } \\
\text { infected plant }\end{array}$ \\
\hline \multirow[t]{3}{*}{$325-4$} & Nontreated & 61 & $91.07 \mathrm{a}$ & $22.33 \pm 2.9 \mathrm{a}$ & $2.65 \pm 0.2 \mathrm{a}$ \\
\hline & K84 & 50 & $4.0 \mathrm{~b}$ & $0.70 \pm 0.02 b$ & $1.00 \pm 0.0 \mathrm{a}$ \\
\hline & K1026 & 57 & $7.00 \mathrm{~b}$ & $0.78 \pm 0.47 b$ & $1.00 \pm 0.0 \mathrm{a}$ \\
\hline \multirow[t]{3}{*}{ K84N6 } & Nontreated & 80 & $97.50 \mathrm{c}$ & $29.73 \pm 2.7 \mathrm{a}$ & $8.34 \pm 0.6 b$ \\
\hline & K84 & 70 & $84.37 \mathrm{~d}$ & $13.37 \pm 2.2 b$ & $3.80 \pm 0.3 \mathrm{a}$ \\
\hline & K1026 & 77 & $81.69 \mathrm{~d}$ & $14.78 \pm 2.6 b$ & $2.89 \pm 0.3 \mathrm{a}$ \\
\hline
\end{tabular}

${ }^{x}$ A. tumefaciens strain 325-4 or K84N6 was introduced into the soil by irrigation with a bacterial suspension to obtain a final concentration of $10^{7} \mathrm{CFU} /$ g of substrate.

y Plants of peach $\times$ almond hybrid GF677 were treated by dipping the roots in a suspension of strain K84 or K1026 peat preparations before being planted in a substrate inoculated individually with each A. tumefaciens strain. Nontreated plants were dipped in water.

$\mathrm{z}$ Tumor formation was recorded 9 months after the treatments. The percentage of infected plants and the number and weight of tumors (mean \pm standard error) per infected plant were determined. A factorial analysis of variance test (two factors: strain and treatment) was used to analyze individually the data obtained. A significant $A$. tumefaciens strain $\times$ treatment interaction was found in the percentage of infected plants, as well as in the number of tumors per infected plant. In these cases, the least significant difference procedure was used to compared means. The weight of the tumors in plants treated with strains K84 and K1026 was not significantly different in plants inoculated with 325-4 and with K84N6, because the sample size in 325-4 was very small. Means within the same treatment followed by different letters are significantly different at $P<0.05$. 
the transconjugant, at least in the tumor environment. The fact that this new Ti plasmid confers oncogenicity, but neither nopaline nor octopine utilization, supports the Ti-plasmid evolution hypothesis previously proposed (25). According to it, related nopaline-type Ti plasmids were derived from a single ancestral nopaline-type $\mathrm{Ti}$ plasmid that has been altered by insertion, deletion, or recombination with other endogenous Agrobacterium plasmids.

Tumor formation was observed in most of the host plants that were inoculated with K84N6, suggesting that the host range of the transconjugant is very similar to that of the parental strain. Thus, although some modifications were found in the genetic structure of the transferred Ti plasmid (42), none of them seems to affect strongly the genes located in the T-DNA and in the vir A and C regions that are involved in host specificity $(2,39)$. In additional studies of virulence on fruit trees, strains K84N6 and 325-4 did not differ in the ability to induce crown gall under field conditions when they were inoculated in the soil. The incidence of crown gall on common hosts of A. tumefaciens (cherry and peach $\times$ almond hybrids GF677 and Adafuel) was very high (50 to 90\%) and similar for both strains. The pathogenic determinants also were stable in Agrobacterium colonies isolated from tumors produced by strain 325-4 or K84N6. All these results suggest that the Ti plasmid-encoded functions for pathogenicity can be expressed in the chromosomal background of strain K84 and do not seem to be incompatible with the new genetic background. Other workers $(22,24,32)$, however, obtained transconjugants from other bacterial species in which the plasmid-encoded functions have changed (i.e., host specificity) compared with the plasmid-donor strains. These authors suggested that the plasmid-encoded functions may be expressed in another genetic background, although some of them may undergo modifications. These changes may be the consequence of a different regulation of expression of plasmid-borne genes in the parental chromosomal background than in the transconjugant (22), of modifications undergone by these genes when transferred to a different bacterium (31), or the consequence of a functional or structural incompatibility of the transferred plasmid with the new chromosomal background (24).

The results of the biological control experiment demonstrated that the wild type, but not the transconjugant, was controlled by strain K84 or K1026. This assay was not repeated because of the difficulties and restrictions of working with genetically modified organisms. However, the high number of plants used for the experiments lends reliability to the results obtained. When strain $325-4$ was used as the pathogen and the plants were treated with strains K84 and K1026, only 4 and 7\%, respectively, of the plants developed galls. In contrast, when strain K84N6 was the pathogen, 84.3 and $81.6 \%$ of the plants treated with strains K84 and K1026, respectively, developed galls. Strain K84N6 harbors pAgK84, a plasmid encoding agrocin 84 production and immunity to it (33). The production of agrocin 84 is one of the main factors involved in the biocontrol by strains K84 and K1026 (14). This could explain why strain K84N6 was not effectively controlled by any of

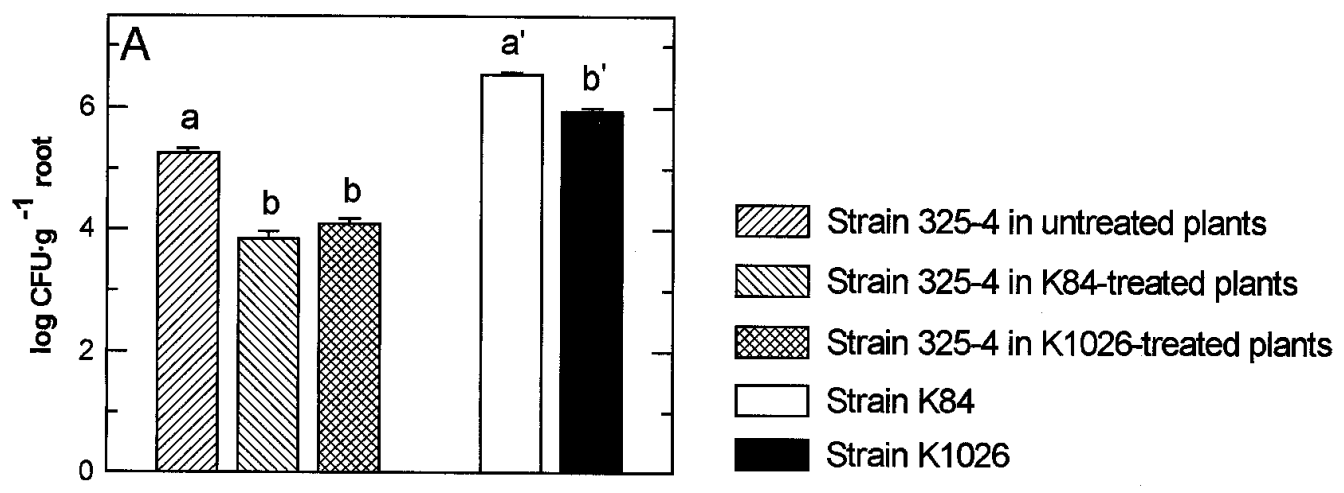

Strain and treatment

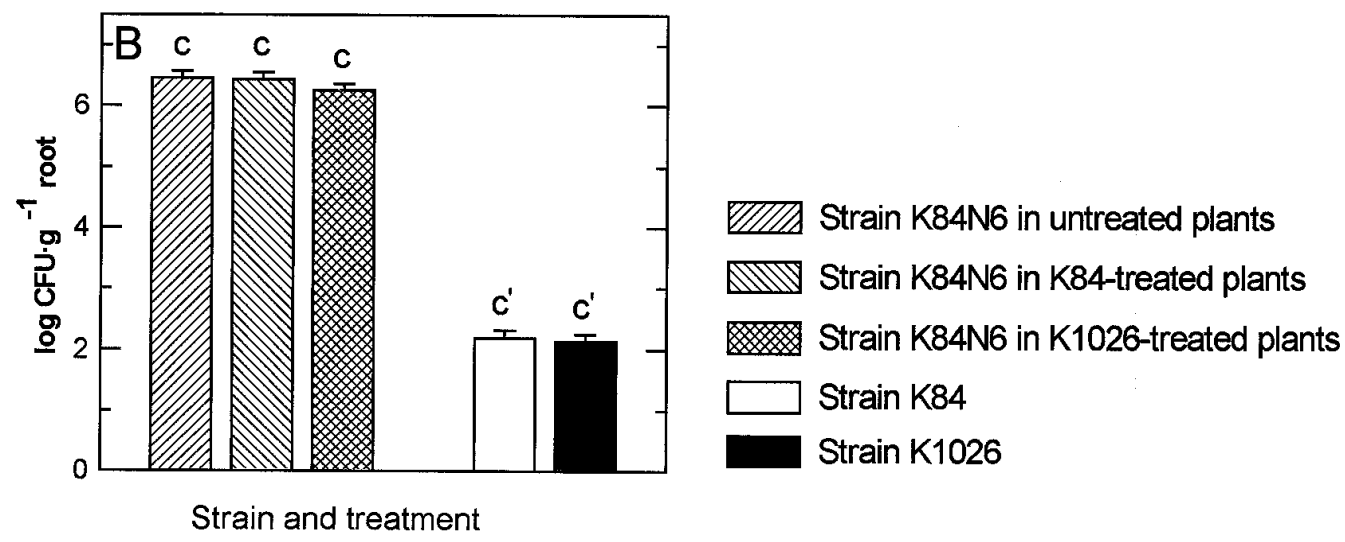

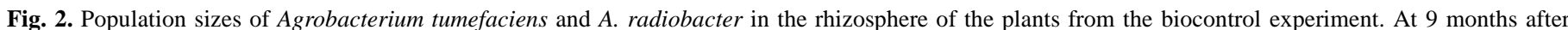

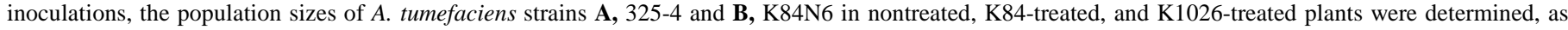

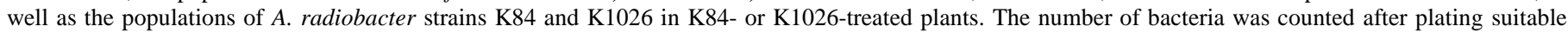

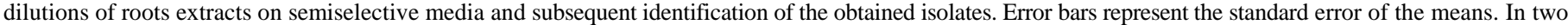

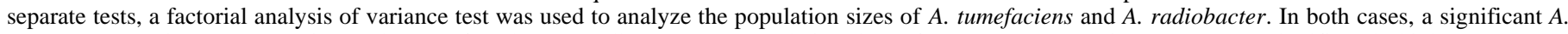

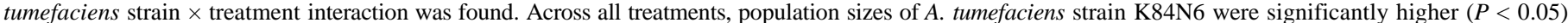

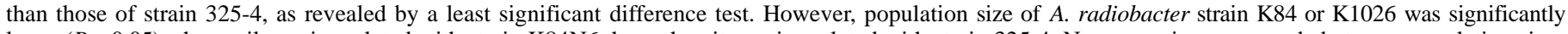

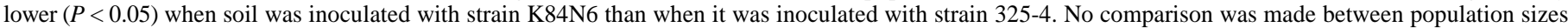
of A. tumefaciens and A. radiobacter. Bars with a different letter are significantly different. 
them, unlike the parental strain $325-4$, which was sensitive to agrocin 84 . However, biocontrol activity of strain K84 or K1026 against some agrocin 84-resistant strains has been reported $(4,18$, 43). In addition to agrocin 84 production, other mechanisms appear to be involved in crown gall suppression including root colonization and production of other antibiotic-like substances $(6,27$, 28). In our experiment, such mechanisms seem to be not as effective, because the transconjugant K84N6 was as good a root colonizer as strain K84 and probably produces the other antibioticlike substances described for this strain. Nevertheless, strains K84 and K1026 still provide a slight, but significant, reduction of crown gall induced by strain K84N6, probably as a consequence of competition for nutrients or habitat or of production of other unknown mechanisms.

Microbial competition is an important factor for establishing bacteria on roots and in the rhizosphere $(1,32)$, and better knowledge of the interactions between bacterial populations is essential for biocontrol. Survival on roots and in the rhizosphere of plasmidcontaining strains was described for other bacterial species as being dependent on the host bacterium that harbors the plasmid (5). However, other authors reported only slight differences in survival between the transconjugant and the plasmid-donor strain $(40,45)$. Our results demonstrated that the population size of the transconjugant was greater than that of the donor strain 325-4 in the rhizosphere of untreated and K84- or K1026-treated plants. Previous treatment of roots with agrocin 84-producing strains K84 or K1026 may favor root colonization by the transconjugant strain K84N6, resistant to this bacteriocin, as compared with the susceptible donor strain 325-4. It has been previously suggested that the inability of the transconjugant to metabolize nopaline could be a disadvantage for the strain. However, strain K84N6 reached higher population sizes in the rhizosphere than the donor strain, even on nontreated plants. Although it was greatly reduced in its ability to utilize nopaline, it may contain other opine-utilization traits, like agrocinopines. Furthermore, opine-utilization traits may be more important for survival in the tumor environment than in the rhizosphere. This was verified by comparing bacterial populations in opine-producing transformed plants (9). Our results indicate a better adaptation of the transconjugant to the rhizosphere habitat. Although previous studies demonstrated that strains K84 and K1026 survive in the rhizosphere in high populations $(27,41)$, in our case, the biocontrol agents were recovered in very low populations from the rhizosphere when the soil was inoculated with the transconjugant. This supports the hypothesis that strain K84N6 is more competitive than strains $\mathrm{K} 84$ and K1026, and the acquisition of the Ti plasmid by K84 background could be the origin of such ability. The horizontal transfer of Ti plasmid in nature is not well documented (8), and the biological relevance of the pTi transfer to strain K84 could be related to its frequency, which seems to be very low (M. J. López-López, unpublished data). The studies of features of the transconjugant strain K84N6 show that even though in some characteristics it does not differ from the donor strain (host range, ability to induce tumors, stability of the pathogenicity), it does differ in the inability to use nopaline and its better survival in roots. Because this kind of pathogenic transconjugants derived from strain K84 cannot be controlled with the available biological methods of crown gall control, the appearance of these transconjugants and their possible dissemination can entail a risk that should be further evaluated.

\section{ACKNOWLEDGMENTS}

This work received support from the Ministry of Agriculture of Spain by grants 8544 and 93117 . We thank G. Bullard for providing strain K1026; F. Temprano and R. Orive for providing peat preparations of strains K84 and K1026; C. Salcedo, C. Morente, and J. Cubero for excellent technical assistance; and E. Carbonell for helpful comments in statistical analysis. M. J. López-López and B. Vicedo contributed equally to this study.

\section{LITERATURE CITED}

1. Bashan, Y. 1986. Enhancement of wheat root colonization and plant development by Azospirillum brasilense Cd. following temporary depression of rhizosphere microflora. Appl. Environ. Microbiol. 51:1067-1071.

2. Buchholz, W. G., and Thomashow, M. F. 1984. Host-range encoded by the Agrobacterium tumefaciens tumor-inducing plasmid pTiAg63 can be expanded by modification of its T-DNA oncogene complement. J. Bacteriol. 160:327-332.

3. Chilton, M. D., Farrand, S. K., Levin, R., and Nester, E. W. 1976. RP4 promotion of transfer of a large Agrobacterium plasmid which confers virulence. Genetics 83:609-618.

4. Cooksey, D. A., and Moore, L. W. 1982. Biological control of crown gall with an agrocin mutant of Agrobacterium radiobacter. Phytopathology 72:919-921.

5. Devanas, M. A., Rafaeli-Eshkol, D., and Stotzky, G. 1986. Survival of plasmid containing strains of Escherichia coli in soil: Effect of plasmid size and nutrients on survival of hosts and maintenance of plasmids. Curr. Microbiol. 13:269-277.

6. Donner, S. C., Jones, D. A., McClure, N. C., Rosewarne, G. M., Tate, M. E., Kerr, A., Fajardo, N. N., and Clare, B. G. 1993. Agrocin 434, a new plasmid encoded agrocin from the biocontrol Agrobacterium strains K84 and K1026 which inhibits biovar 2 agrobacteria. Physiol. Mol. Plant Pathol. 42:185-194.

7. Ellis, J. G., Kerr, A., Petit, A., and Tempé, J. 1982. Conjugal transfer of nopaline and agropine Ti-plasmids. The role of agrocinopines. Mol. Gen. Genet. 186:269-278

8. Farrand, S. K. 1993. Conjugal transfer of Agrobacterium plasmids. Pages 255-291 in: Bacterial Conjugation. D. B. Clewell, ed. Plenum Press, New York.

9. Guyon, P., Petit, A., Tempé, J., and Dessaux, Y. 1993. Transformed plants producing opines specifically promote grown of opine-degrading agrobacteria. Mol. Plant-Microbe Interact. 6:92-98.

10. Jones, D. A., and Kerr, A. 1989. Agrobacterium radiobacter K1026, a genetically engineered derivative of strain $\mathrm{K} 84$, for biological control of crown gall. Plant Dis. 73:15-18.

11. Jones, D. A., Ryder, M. H., Clare, B. G., Farrand, S. K., and Kerr, A. 1988. Construction of a Tra ${ }^{-}$deletion mutant of pAgK84 to safeguard the biological control of crown gall. Mol. Gen. Genet. 212:207-214.

12. Kado, C. I. 1991. Molecular mechanisms of crown gall tumorigenesis. Crit. Rev. Plant Sci. 10:1-32.

13. Kerr, A. 1969. Transfer of virulence between isolates of Agrobacterium. Nature (Lond.) 223:1175-1176.

14. Kerr, A., and Htay, K. 1974. Biological control of crown gall through bacteriocin production. Physiol. Plant Pathol. 4:37-44.

15. Law, I. J., and Strijdom, B. W. 1989. Negative effects of agrocin 84encoding Agrobacterium plasmids on symbiotic properties of Rhizobium meliloti. Arch. Microbiol. 152:463-467.

16. Lippincott, J. A., Beiderbeck, R., and Lipincott, B. B. 1973. Utilization of octopine and nopaline by Agrobacterium tumefaciens. J. Bacteriol. 116:378-383.

17. López, M. M., Gorris, M. T., and Montojo, A. M. 1988. Opine utilization by Spanish isolates of Agrobacterium tumefaciens. Plant Pathol. 37:565-572.

18. López, M. M., Gorris, M. T., Salcedo, C. I., Montojo, A. M., and Miró, M. 1989. Evidence of biological control of Agrobacterium tumefaciens strains sensitive and resistant to agrocin 84 by different $A$. radiobacter strains on stone fruit trees. Appl. Environ. Microbiol. 55:741-746.

19. López, M. M., Miró, M., Orive, R., Temprano, F., and Poli, M. 1982. Biological control of crown gall of rose in Spain. Pages 538-548 in: Proc. Int. Conf. Plant Pathogenic Bacteria, 5th. J. Lozano and P. Gwin, eds. CIAT, Cali, Colombia.

20. Moore, L. W., Kado, C. I., and Bouzar, H. 1988. Agrobacterium. Pages 16-36 in: Laboratory Guide for Identification of Plant Pathogenic Bacteria. 2nd ed. N. W. Schaad, ed. The American Phytopathological Society, St. Paul, MN.

21. Moore, L. W., and Warren, G. 1979. Agrobacterium radiobacter strain K84 and biological control of crown gall. Annu. Rev. Phytopathol. 7:163-179.

22. Moulton, P. J., Vivian, A., Hunter, P. J., and Taylor, J. D. 1993. Changes in cultivar-specificity toward pea can result from transfer of plasmid RP4 and other incompatibility group P1 replicons to Pseudomonas syringae pv. pisi. J. Gen. Microbiol. 139:3149-3155.

23. New, P. B., and Kerr, A. 1971. A selective medium for Agrobacterium radiobacter biotype 2. J. Appl. Bacteriol. 34:233-239.

24. Novikova, N., and Safronova, V. 1992. Transconjugants of Agrobacterium radiobacter harbouring sym genes of Rhizobium galegae can form an effective symbiosis with Medicago sativa. FEMS Microbiol. Lett. 93: 261-268.

25. Otten, L., Canaday, J., Gérard, J.-C., Fournier, P., Crouzet, P., and Paulus, F. 1992. Evolution of agrobacteria and their Ti plasmid-A review. Mol. Plant-Microbe Interact. 5:279-287. 
26. Panagopoulos, C. G., Psallidas, P. G., and Alivizatos, A. S. 1979. Evidence of a breakdown in the effectiveness of biological control of crown gall. Pages 569-578 in: Soil-Borne Plant Pathogens. B. Schippers and W. Gams, eds. Academic Press, London.

27. Peñalver, R. 1994. Effectiveness of Agrobacterium radiobacter in the biological control of Agrobacterium tumefaciens and involved mechanisms. Ph.D. thesis. University of Valencia, Valencia, Spain.

28. Peñalver, R., Vicedo, B., Salcedo, C. I., and López, M. M. 1994. Agrobacterium radiobacter strains K84, K1026 and K84 Agr- produce an antibioticlike substance, active in vitro against $A$. tumefaciens and phytopathogenic Erwinia and Pseudomonas spp. Biocontrol Sci. Technol. 4:259-267.

29. Petit, A., David, C., Ellis, G. J., Guyon, P. G., Case-Delbart, F., and Tempé, J. 1983. Further extension of the opine concept: Plasmids in Agrobacterium rhizogenes cooperate for opine degradation. Mol. Gen. Genet. 190:204-214.

30. Petit, A., Tempé, J., Kerr, A., Holsters, M., Van Montagu, M., and Schell, J. 1978. Substrate induction of conjugative activity of Agrobacterium tumefaciens Ti plasmids. Nature 271:570-572.

31. Ramos-González, M. I., Duque, E., and Ramos, J. L. 1991. Conjugational transfer of recombinant DNA in cultures and in soils: Host range of Pseudomonas putida TOL plasmids. Appl. Environ. Microbiol. 57:30203027.

32. Richaume, A., Bernillon, D., and Faurie, G. 1992. Role of the intraspecific competition in the regulation of Agrobacterium tumefaciens transconjugant population level in soil experiments. FEMS Microbiol. Ecol. 86:321-330.

33. Ryder, M. H., Slota, J. E., Scarim, A., and Farrand, S. K. 1987. Genetic analyses of agrocin 84 production and immunity in Agrobacterium spp. J. Bacteriol. 169:4184-4187.

34. Sans, N., Schröder, G., and Schröder, J. 1987. The noc region of Ti plasmid C58 codes for arginase and ornithine cyclodeaminase. Eur. J. Biochem. 167:81-87.

35. Schaad, N. W., Süle, S., Van Vuurde, J. W. L., Vrugging, H., Alvarez, A. M., Benedict, A. A., De Wael, L., and Van Laere, O. 1990. Serology. Pages 153-190 in: Methods in Phytobacteriology. Z. Klement, K. Rudolph, and D. C. Sands, eds. Akadémiai Kiadó, Budapest.
36. Schroth, M. N., Thompson, J. P., and Hildebrand, D. C. 1965. Isolation of Agrobacterium tumefaciens-A. radiobacter group from soil. (Abstr.) Phytopathology 55:645.

37. Stockwell, V. O., Kawalek, M. D., Moore, L. W., and Loper, J. E. 1996. Transfer of pAgK84 from the biocontrol agent Agrobacterium radiobacter K84 to A. tumefaciens under field conditions. Phytopathology 86:31-37.

38. Stonier, T. 1960. Agrobacterium tumefaciens Conn. II. Production of an antibiotic substance. J. Bacteriol. 72:259-268.

39. Turk, S. C. H. J., Nester, E. W., and Hooykaas, P. J. J. 1993. The vir A promoter is a host-range determinant in Agrobacterium tumefaciens. Mol. Microbiol. 7:719-724.

40. Van Elsas, J. D., Van Overbeek, L. S., Feldmann, A. M., Dullemans, A. M., and de Leeuw, D. 1991. Survival of genetically engineered Pseudomonas fluorescens in soil in competition with the parental strain. FEMS Microbiol. Ecol. 85:53-64.

41. Vicedo, B. 1995. Plasmid transfer between Agrobacterium tumefaciens and $A$. radiobacter in biological control assays: Characterization and behavior of the transconjugants. Ph.D. thesis. University of Valencia, Valencia, Spain.

42. Vicedo, B., López-López, M. J., Asíns, M. J., and López, M. M. 1996. Spontaneous transfer of the Ti plasmid of Agrobacterium tumefaciens and the nopaline catabolism plasmid of $A$. radiobacter strain $\mathrm{K} 84$ in crown gall tissue. Phytopathology 86:528-534.

43. Vicedo, B., Peñalver, R., Asíns, M. J., and López, M. M. 1993. Biological control of Agrobacterium tumefaciens, colonization and pAgK84 transfer with Agrobacterium radiobacter $\mathrm{K} 84$ and the $\mathrm{Tra}^{-}$mutant strain K1026. Appl. Environ. Microbiol. 59:309-315.

44. Walpole, R. E., and Myers, R. M. 1979. Probability and Statistics for Engineers and Scientists. Macmillan Company, New York.

45. Wang, Z., Crawford, D. L., Pometto, III, A. L., and Rafii, F. 1989. Survival of wild type, mutant and recombinant Streptomyces in a soil ecosystem. Can. J. Microbiol. 35:535-543.

46. Zanker, H., Lurz, G., Langridge, P., Kreusch, D., and Schröder, J. 1994 Octopine and nopaline oxidases from Ti plasmids of Agrobacterium tumefaciens: Molecular analysis, relationship and functional characterization. J. Bacteriol. 176:4511-4517. 